\title{
Analisis dan Evaluasi Kestabilan Tegangan dengan Metode Continuation Power Flow (CPF) pada Sistem Microgrid
}

\author{
Radhilia Sofianna Ruzi, Ontoseno Penangsang, dan Ni Ketut Aryani \\ Jurusan Teknik Elektro, Fakultas Teknologi Industri, Institut Teknologi Sepuluh Nopember (ITS) \\ Jl. Arief Rahman Hakim, Surabaya 60111 Indonesia \\ e-mail: radhilia.sofianna.ruzi@gmail.com,zenno_379@yahoo.com
}

\begin{abstract}
Abstrak-Tugas akhir ini bertujuan untuk menganalisis kestabilan tegangan pada sistem microgrid akibat adanya penambahan beban secara kontinyu sehingga terjadi ketidak mampuan sistem dalam mengendalikan atau mempertahankan tegangan pada masing-masing bus. Penyelesaian tugas akhir diawali dengan mengetahui aliran daya pada sistem dengan menggunakan metode "BackwardForward Sweep" kemudian dilanjutkan dengan mengunakan Continuation Power Flow (CPF) sebagai metode untuk mengidentifikasi bus sistem yang paling sensitif mengalami jatuh tegangan serta mendapatkan nilai pembebanan maksimum pada masing-masing bus. Analisis dan simulasi kedua metode ini dilakukan pada jaring distribusi radial IEEE 33 bus dan IEEE 69 bus ${ }^{[1]}$. Efek daripada penempatan DG yang tepat dengan metode Continuation Power Flow (CPF) adalah dapat meningkatkan profil tegangan dan dapat mengatasi ketidak-stabilan tegangan, sehingga analisis dan evaluasi kestabilan tegangan dapat terlihat saat kondisi sebelum dan sesudah penambahan DG.
\end{abstract}

Kata Kunci-Backward-Forward Sweep, Continuation Power Flow (CPF), Distributed Generation (DG), Sistem Distribusi Radial, Voltage Stability.

\section{Pendahuluan}

$\mathrm{K}$ estabilan tegangan berkaitan dengan kemampuan sistem tenaga listrik untuk mempertahankan tegangan di setiap bus pada kondisi abnormal maupun karena adanya gangguan ${ }^{[2]}$. Sistem akan memasuki keadaan ketidakstabilan tegangan ketika terjadi gangguan, peningkatan permintaan beban dan adanya perubahan kondisi sistem. Keadaan tersebut akan menyebabkan penurunan performa sistem, sehingga tegangan menjadi tidak terkendali, akibatnya profil tegangan menurun dan kerugian daya (Losses) pada sistem distribusi semakin besar, akibat fatal dari kondisi tersebut adalah terjadinya pemadaman atau blackout pada daerah sekitar.

Ketersediaan DG umumnya dalam skala kecil yaitu 1 Watt hingga $300 \mathrm{Mw}^{[4]}$. Oleh sebab itu untuk mensuplai konsumen pada skala besar penggunaan DG harus tetap tehubung dengan Grid, namun penggunaan penetrasi DG yang berlebih dapat mempengaruhi sistem distribusi hingga sistem transmisi, akibatnya hubungan antara DG dengan Grid dapat mempengaruhi kestabilan sistem seperti : frekuensi, proteksi dan kestabilan tegangan ${ }^{[5]}$.

Oleh karena itu, dalam tugas akhir ini diusulkan sebuah metode untuk menganalisis kestabilan tegangan yang terjadi pada sistem distribusi radial dengan penambahan DG atau disebut juga dengan Microgrid on
Grid Model sebagai dasar pertimbangan dalam penempatan DG sehingga profil tegangan dapat meningkat dan dapat mengatasi masalah ketidak-stabilan tegangan.

Tugas akhir ini mengusulkan sebuah metode untuk penempatan DG pada jaring distribusi berdasarkan analisis CPF dengan cara menentukan bus yang paling sensitif (Sensitive Bus) terjadi voltage collapse akibat adanya penambahan beban secara kontinyu tanpa mempertimbangkan rating peralatan, setelah itu DG dengan kapasitas tertentu akan dipasang pada sensitive bus hingga objective function terpenuhi ${ }^{[6]}$ yaitu meningkatnya profil tegangan.

\section{Pemodelan Sistem}

Continuation Power Flow pada umumnya menggunakan metode newton rapshon untuk menghitung aliran daya dari sebuah sistem tenaga yang digunakan sebagai data awal yang selanjutnya akan diolah untuk membentuk kurva P-V dengan adanya penambahan beban secara terus menerus, namun dalam kondisi penggunaan metode newton raphson pada sistem tertentu matriks Jacobian yang dihasilkan menjadi singular, dampak dari hal tersebut adalah metode ini akan menghasilkan numerical perhitungan yang sulit.

Pada tugas akhir ini sistem yang akan dianalisis adalah sistem distribusi radial IEEE 33 bus dan IEEE 69 bus, apabila sistem ini menggunakan metode newton raphson power flow untuk menghitung aliran daya sistem, maka matrix jacobian yang dihasilkan menjadi kurang konvergen karena nilai ratio $\mathrm{R} / \mathrm{X}$ pada sistem yang tinggi, akibatnya kurva yang dihasilkan cenderung tidak stabil. Oleh sebab itu, pada tugas akhir ini akan menggunakan perhitungan Continuation Power Flow dengan menggunakan first-order polynominal secant predictor dan hasilnya akan dikoreksi dengan menggunakan metode backward/forward radial power flow.

\section{A. Continuation Power Flow}

Continuation Power Flow dengan menggunakan firstorder polynominal secant predictor yang hasilnya akan dikoreksi dengan menggunakan metode backward/forward radial power flow memiliki beberapa kentungan diantaranya adalah ${ }^{[10]}$ :

1. Masalah singularitas yang berhubungan dengan classical Jacobian matrix-based power-flow methods menghilang. 
2. Lebih efesien dalam menangani sistem dengan berbagai sistem dan beban tidak seimbang.

3. Lebih efesien dalam menangani sistem dengan ratio $\mathrm{R} / \mathrm{X}$ yang tinggi.

4. Waktu iterasi lebih cepat terutama dalam menangani sistem 3 fasa tidak seimbang.

Proses solusi prediktor dan korektor pada Continuation Power Flow digunakan sebagai proses pengolahan kurva PV hingga mendapatkan kondisi pembebanan maksimum. Pertama, inisialisasi awal solusi aliran daya dilakukan untuk meghitung tegangan dengan penambahan beban secara kontinyu, penambahan bebab dilakukan berdasarkan secant predictor, hasil perhitungan tegangan dengan penambahan beban tersebut dikoreksi menggunakan aliran daya backward/forward sweep dengan solusi iteratif. Solusi iteratif aliran daya akan berulang hingga mencapai toleransi ketidak cocokan yang telah ditetapkan seperti yang terlihat pada persamaan (1) dan (2). Proses penambahan solusi prediktor dan korektor pada Continuation Power Flow akan berulang secara terus menerus hingga parameter ukuran kontrol kurang dari nilai toleransi yang diberikan pada persamaan (5) ketika perulangan tersebut berhenti maka akan didapatkan nilai tegangan pada kondisi pembebanan maksimum.

$$
\begin{aligned}
& \Delta P_{i}<\varepsilon_{P F} \\
& \Delta Q_{i}<\varepsilon_{P F}
\end{aligned}
$$

Dimana $\triangle \mathrm{Pi}$ dan $\Delta \mathrm{Qi}$ merupakan ketidak sesuaian daya aktif dan reaktif di bus $\mathrm{i}$ dan $\varepsilon_{P F}$ adalah nilai toleransi aliran daya yang telah ditetapkan.

$$
\sigma_{k}<\varepsilon_{M L P}
$$

Dimana $\sigma_{k}$ adalah ukuran kontrol penambahan beban, sedangkan $\varepsilon_{M L P}$ adalah definisi dari nilai toleransi untuk menentukan Maximum Loading Point (MLP), dalam proses prediktor dan korektor diperlukan perhitungan dua titik pertama pada kurva dengan menggunakan Adaptive step (ג). Namun, ukuran step yang digunakan akan dikontrol dengan persamaan sebagai berikut :

$$
\begin{aligned}
\sigma_{k+1} & =\sigma_{k} \frac{C}{n_{k}} \\
\lambda_{k+1} & =\sigma_{k}+\lambda_{k}
\end{aligned}
$$

Dimana $\mathrm{C}$ adalah parameter ukuran kontrol sedangkan $n_{k}$ adalah banyaknya jumlah iterasi aliran daya saat $\mathrm{k}, \mathrm{k}$ merupakan nilai iterasi pada Continuation Power Flow. Setiap ukuran langkah akan diperbarui sesuai dengan persamaan (5), kemudian parameter yang baru dihitung kembali menggunakan persamaan (4). Setiap ukuran langkah yang telah ditentukan maka tegangan terbaru dapat ditentukan, tegangan terbaru pada bus akan dihitung menggunakan persamaan (6) dan (7).

$$
\begin{aligned}
& V=-\frac{\left(\lambda_{k-1}\right)-\left(\lambda_{k}\right)}{\left(\lambda_{k-1}\right)-\left(\lambda_{k-2}\right)}\left[\left(V_{k-1}\right)-\left(V_{k-2}\right)+\left(V_{k-1}\right)\right] \\
& \delta=-\frac{\left(\lambda_{k-1}\right)-\left(\lambda_{k}\right)}{\left(\lambda_{k-1}\right)-\left(\lambda_{k-2}\right)}\left[\left(\delta_{k-1}\right)-\left(\delta_{k-2}\right)+\left(\delta_{k-1}\right)\right]
\end{aligned}
$$

Sedangkan bus data pada setiap ukuran langkah yang telah ditentukan juga akan dihitung menggunakan persamaan (8), dimana $\mathrm{K}$ adalah load multiplier.

$$
P_{(n k, i)}=(1+\lambda \cdot K) P_{(n k, 0)}
$$

\section{B. Backward/Forward Sweep Load Flow}

Analisis aliran daya pada sistem distribusi radial memiliki banyak cabang dan banyak beban terpasang, hal tersebut menyebabkan ratio $\mathrm{R} / \mathrm{X}$ tinggi, oleh sebab metode backward-forward sweep adalah metode yang paling tepat untuk diaplikasikan ke sistem distribusi radial. Langkah awal dari metode Backward - Forward Sweep adalah menghitung besar arus yang mengalir pada saluran, dari bus paling awal hingga akhir yang disebut dengan backward sweep dan yang kedua adalah mengitung nilai drop tegangan pada setiap saluran dengan mengkalikan nilai arus yang telah dihitung sebelumnya dengan nilai impedansi salurannya yang disebut dengan forward sweep.

Gambar. 1. merupakan salah satu contoh dari gambar single line diagram untuk pembentukan matrik dalam persamaan aliran daya.

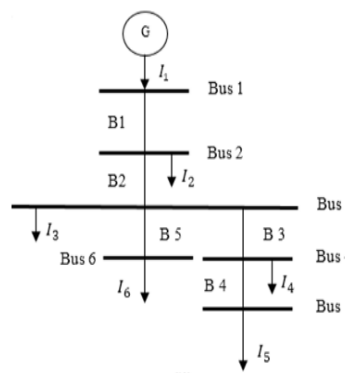

Gambar 1. Single Line Diagram ${ }^{[12]}$

Untuk menghitung arus cabang didapatkan dari hubungan daya kompleks dan tegangan pada setiap bus, seperti persamaan dibawah ini :

$$
I_{i}^{k}=\operatorname{conj}\left(\frac{P_{i}+j Q_{i}}{V_{i}^{k}}\right)
$$

Dimana :

$I_{i}^{k} \quad=$ Arus pada bus I saat iterasi ke-K

$V_{i}^{k} \quad=$ Tegangan pada bus I saat iterasi ke-K

Metode Backward-Forward Sweep membutuhkan modifikasi perhitungan untuk memudahkan dalam membentuk persamaan dan proses iterasi sehingga dapat menghitung nilai tegangan di setiap bus nya, proses modifikasi tersebut berupa persamaan matrik BIBC (Bus Injection to Branch Current), matrik BIBC adalah matrik hubungan antara arus dan saluran pada sistem.

Gambar single line diagram diatas menghasilkan persamaan untuk membentuk matrik BIBC, dengan menggunakan hukum kirchoff untuk arus. Arus cabang I terhadap bus atau saluran B, maka persamaan yang didapat adalah seperti berikut :

$$
\begin{aligned}
& B_{5}=I_{6} \\
& B_{4}=I_{5} \\
& B_{3}=I_{4}+I_{5} \\
& B_{2}=I_{3}+I_{4}+I_{5}+I_{6} \\
& B_{1}=I_{2}+I_{3}+I_{4}+I_{5}+I_{6}
\end{aligned}
$$

Dimana :

$\mathrm{B}_{\mathrm{n}} \quad=$ Saluran Bus $\mathrm{n}$

$\mathrm{I}_{\mathrm{n}} \quad=$ Arus Cabang $\mathrm{n}$

Persamaan (10) merupakan persamaan arus cabang I terhadap bus, dimana persamaan tersebut akan dibentuk matrik BIBC seperti berikut :

$$
\begin{aligned}
& {\left[\begin{array}{l}
B_{1} \\
B_{2} \\
B_{3} \\
B_{4} \\
B_{5}
\end{array}\right]=\left[\begin{array}{lllll}
1 & 1 & 1 & 1 & 1 \\
0 & 1 & 1 & 1 & 1 \\
0 & 0 & 1 & 1 & 0 \\
0 & 0 & 0 & 1 & 0 \\
0 & 0 & 0 & 0 & 1
\end{array}\right]\left[\begin{array}{l}
I_{1} \\
I_{2} \\
I_{3} \\
I_{4} \\
I_{5}
\end{array}\right]} \\
& {[B]=[\boldsymbol{B I} \boldsymbol{B} \boldsymbol{C}][I]}
\end{aligned}
$$

Angka 1 Menyatakan adanya hubungan antara arus dan saluran pada sistem, sedangkan angka 0 menyatakan 
tidak adanya hubungan antara arus dan saluran pada sistem, Matriks 1 \& 0 yang disebut dengan matriks BIBC. Drop tegangan pada setiap bus dapat ditentukan dengan cara mengkalikan nilai arus yang telah dihitung sebelumnya dengan nilai impedansi salurannya yang disebut dengan forward sweep. Hasil persamaan tersebut dapat dilihat pada persamaan (13).

$$
\begin{aligned}
& V_{2}=V_{1}-B_{1} \cdot Z_{12} \\
& V_{3}=V_{1}-B_{1} \cdot Z_{12}-B_{2} \cdot Z_{23} \\
& V_{4}=V_{1}-B_{1} \cdot Z_{12}-B_{2} \cdot Z_{23}-B_{3} \cdot Z_{34} \\
& V_{5}=V_{1}-B_{1} \cdot Z_{12}-B_{2} \cdot Z_{23}-B_{3} \cdot Z_{34}-B_{4} \cdot Z_{45} \\
& V_{6}=V_{1}-B_{1} \cdot Z_{12}-B_{2} \cdot Z_{23}-B_{3} \cdot Z_{34}-B_{4} \cdot Z_{45}- \\
& B_{5} \cdot Z_{26}
\end{aligned}
$$

Dimana :

$\mathrm{V}_{\mathrm{n}} \quad=$ Tegangan Bus $\mathrm{n}$

$\mathrm{B}_{\mathrm{n}} \quad=$ Saluran Bus $\mathrm{n}$

$\mathrm{Z}_{\mathrm{k}-\mathrm{l}} \quad=$ Impedansi Saluran dari bus k ke bus 1

Matrik BCBV (Branch Current to Branch Voltage) adalah matrik hubungan antara tegangan bus dan arus saluran yang didapat dari penurunan persamaan (14), jika dibentuk sebagai sebuah matrik akan menjadi sebagai berikut :

$\left[\begin{array}{l}V_{1}-V_{2} \\ V_{1}-V_{3} \\ V_{1}-V_{4} \\ V_{1}-V_{5} \\ V_{1}-V_{6}\end{array}\right]=\left[\begin{array}{ccccc}Z_{12} & 0 & 0 & 0 & 0 \\ Z_{12} & Z_{23} & 0 & 0 & 0 \\ Z_{12} & Z_{23} & Z_{34} & 0 & 0 \\ Z_{12} & Z_{23} & Z_{34} & Z_{45} & 0 \\ Z_{12} & Z_{23} & 0 & 0 & Z_{36}\end{array}\right]\left[\begin{array}{l}B_{1} \\ B_{2} \\ B_{3} \\ B_{4} \\ B_{5}\end{array}\right]$

$[\Delta V]=[\boldsymbol{B} \boldsymbol{C} \boldsymbol{B} \boldsymbol{V}][B]$

Dimana :

$$
\begin{array}{ll}
\mathrm{V}_{\mathrm{n}} & =\text { Tegangan Bus } \mathrm{n} \\
\mathrm{B}_{\mathrm{n}} & =\text { Saluran Bus } \mathrm{n} \\
\mathrm{Z}_{\mathrm{k}-\mathrm{l}} & =\text { Impedansi Saluran dari bus k ke bus } 1 \\
\Delta V & =\text { Drop Tegangan antara } \mathrm{V}_{\mathrm{k}} \text { ke } \mathrm{V}_{\mathrm{l}}
\end{array}
$$

Distribution Load Flow (DLF) merupakan hasil perkalian antara matrik BCBV dan matrik BIBC yang digunakan untuk mendapatkan persamaan untuk menghitung nilai drop tegangan pada setiap bus. Persamaan untuk matrik dari drop tegangan $(\Delta \mathrm{V})$, persamaan yang didapat adalah sebagai berikut :

$$
\begin{aligned}
& {[\Delta V]=[\boldsymbol{B C} \boldsymbol{B} \boldsymbol{V}][\boldsymbol{B} \boldsymbol{I B} \boldsymbol{C}][I]} \\
& {[\Delta V]=[\boldsymbol{D L} \boldsymbol{F}][I]}
\end{aligned}
$$

Dengan didapatkannya matrik BIBC, BCBV dan $\Delta V$, tegangan pada setiap bus dapat dihitung menggunakan persamaan dibawah ini :

$$
[\mathrm{Vi}]=[\mathrm{V} 1]-[\Delta \mathrm{V}]
$$

Dimana :

$\Delta V \quad=$ Drop Tegangan antara $\mathrm{V}_{\mathrm{k}}$ ke $\mathrm{V}_{\mathrm{l}}$

$\mathrm{BCBV}=$ Matrik Branch Current to Branch Voltage

\begin{tabular}{|c|c|c|c|c|c|c|c|}
\hline \multirow[b]{2}{*}{ Bus } & \multirow[b]{2}{*}{$\begin{array}{c}\text { Dari } \\
\text { bus }\end{array}$} & \multirow[b]{2}{*}{$\begin{array}{c}\text { Ke } \\
\text { bus }\end{array}$} & \multirow[b]{2}{*}{$\mathbf{R}(\Omega)$} & \multirow[b]{2}{*}{$\mathbf{X}(\Omega)$} & \multicolumn{3}{|c|}{ Daya Nominal } \\
\hline & & & & & $\begin{array}{c}\mathbf{P} \\
(\mathbf{k W})\end{array}$ & $\begin{array}{c}\mathbf{Q} \\
(\mathrm{kVAR})\end{array}$ & $\begin{array}{c}\mathrm{S} \\
(\mathbf{k V A})\end{array}$ \\
\hline 2 & 1 & 2 & 0.0922 & 0.047 & 100 & 60 & 116.619 \\
\hline 3 & 2 & 3 & 0.493 & 0.2511 & 90 & 40 & 98.489 \\
\hline 4 & 3 & 4 & 0.366 & 0.1864 & 120 & 80 & 144.222 \\
\hline 5 & 4 & 5 & 0.3811 & 0.1941 & 60 & 30 & 67.082 \\
\hline 6 & 5 & 6 & 0.819 & 0.707 & 60 & 20 & 63.246 \\
\hline 7 & 6 & 7 & 0.1872 & 0.6188 & 200 & 100 & 223.607 \\
\hline 8 & 7 & 8 & 0.7144 & 0.2351 & 200 & 100 & 223.607 \\
\hline 9 & 8 & 9 & 1.03 & 0.74 & 60 & 20 & 63.246 \\
\hline 10 & 9 & 10 & 1.044 & 0.74 & 60 & 20 & 63.246 \\
\hline 11 & 10 & 11 & 0.1966 & 0.065 & 45 & 30 & 54.083 \\
\hline 12 & 11 & 12 & 0.3744 & 0.1298 & 60 & 35 & 69.462 \\
\hline 13 & 12 & 13 & 1.468 & 1.155 & 60 & 35 & 69.462 \\
\hline 14 & 13 & 14 & 0.5416 & 0.7129 & 120 & 80 & 144.222 \\
\hline 15 & 14 & 15 & 0.591 & 0.526 & 60 & 10 & 60.828 \\
\hline 16 & 15 & 16 & 0.7463 & 0.545 & 60 & 20 & 63.246 \\
\hline 17 & 16 & 17 & 1.289 & 1.721 & 60 & 20 & 63.246 \\
\hline 18 & 17 & 18 & 0.732 & 0.574 & 90 & 40 & 98.489 \\
\hline 19 & 2 & 19 & 0.164 & 0.1565 & 90 & 40 & 98.489 \\
\hline 20 & 19 & 20 & 1.5042 & 1.3554 & 90 & 40 & 98.489 \\
\hline 21 & 20 & 21 & 0.4095 & 0.4784 & 90 & 40 & 98.489 \\
\hline
\end{tabular}

BIBC = Matrik Bus Injection to Branch Current

DLF = Matrik Distributin Load Flow

$\mathrm{V}_{\mathrm{i}} \quad=$ Tegangan Saluran Bus i

\section{Test System IEEE 33 bus dan IEEE 69 bus}

Sistem kelistrikan yang akan digunakan dalam analisis dan evaluasi kestabilan tegangan adalah sistem kelistrikan IEEE 33 Bus dan IEEE 69 Bus $^{[1]}$ seperti pada Gambar 2.

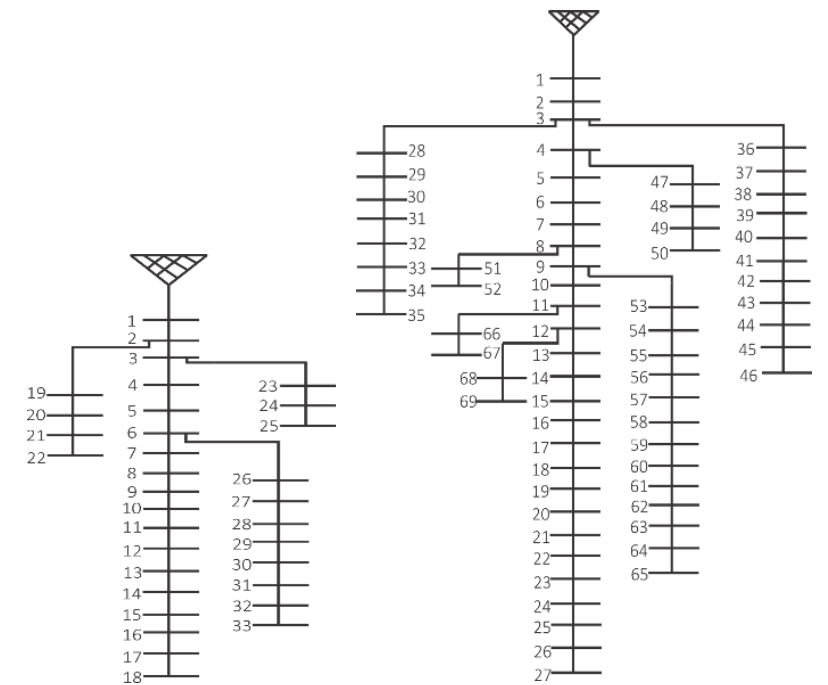

Gambar 2. Sistem Kelistrikan IEEE 33 Bus (Kiri) dan IEEE 69 Bus (Kanan)

TABel 1. Line DATA DAN Bus Data IEEE 33 Bus

TABel 1. Line Data dan Bus Data IEEE 33 Bus (LANJUTAN)

\begin{tabular}{cccccccc}
\hline \hline & & & & & \multicolumn{3}{c}{ Daya Nominal } \\
\cline { 7 - 8 } Bus & $\begin{array}{c}\text { Dari } \\
\text { bus }\end{array}$ & $\begin{array}{c}\text { Ke } \\
\text { bus }\end{array}$ & $\mathbf{R}(\mathbf{\Omega})$ & $\mathbf{X}(\mathbf{\Omega})$ & $\mathbf{P}$ & $\mathbf{Q}$ & $\mathbf{S}$ \\
\hline 22 & 21 & 22 & 0.7089 & 0.9373 & 90 & 40 & 98.489 \\
23 & 3 & 23 & 0.4512 & 0.3083 & 90 & 50 & 102.956 \\
24 & 23 & 24 & 0.898 & 0.7091 & 420 & 200 & 465.188 \\
25 & 24 & 25 & 0.896 & 0.7011 & 420 & 200 & 465.188 \\
26 & 6 & 26 & 0.203 & 0.1034 & 60 & 25 & 65.000 \\
27 & 26 & 27 & 0.2842 & 0.1447 & 60 & 25 & 65.000 \\
28 & 27 & 28 & 1.059 & 0.9337 & 60 & 20 & 63.246 \\
29 & 28 & 29 & 0.8042 & 0.7006 & 120 & 70 & 138.924 \\
30 & 29 & 30 & 0.5075 & 0.2585 & 200 & 600 & 632.456 \\
31 & 30 & 31 & 0.9744 & 0.963 & 150 & 70 & 165.529 \\
32 & 31 & 32 & 0.3105 & 0.3619 & 210 & 100 & 232.594 \\
33 & 32 & 33 & 0.341 & 0.5302 & 60 & 40 & 72.111 \\
\hline
\end{tabular}




\begin{tabular}{|c|c|c|c|c|c|c|c|}
\hline \multicolumn{5}{|c|}{ TOTAL } & 715 & 300 & 9.351 \\
\hline \multirow[b]{3}{*}{ Bus } & \multirow[b]{3}{*}{$\begin{array}{l}\text { Dari } \\
\text { bus }\end{array}$} & \multirow[b]{3}{*}{$\begin{array}{l}\text { Ke } \\
\text { bus }\end{array}$} & \multirow[b]{3}{*}{$\mathbf{R}(\mathbf{\Omega})$} & \multirow[b]{3}{*}{ ( $\mathbf{\Omega})$} & \multirow{2}{*}{\multicolumn{3}{|c|}{ Daya Nominal }} \\
\hline & & & & & & & \\
\hline & & & & & $\begin{array}{c}\mathbf{P} \\
(\mathbf{M W})\end{array}$ & $\begin{array}{c}\mathbf{Q} \\
\text { (MVAR) }\end{array}$ & $\begin{array}{c}\mathbf{S} \\
\text { (MVA) }\end{array}$ \\
\hline 2 & 1 & 2 & 0.0005 & 0012 & 0.0000 & 0.0000 & 0.0000 \\
\hline 3 & 2 & 3 & 0005 & 0.0012 & 0.0000 & 0.0000 & 0.0000 \\
\hline 4 & 3 & 4 & & & & 0.0000 & 0000 \\
\hline 5 & 4 & 5 & 1 & 0.0294 & 0.0000 & 0.0000 & 0.0000 \\
\hline 6 & 5 & 6 & 3660 & & 0.0026 & 0.0022 & 0.0048 \\
\hline 7 & 0 & 7 & 1 & 1941 & 0.0404 & 0.0300 & 0.0704 \\
\hline 8 & 7 & 8 & 0.0922 & & 0.0750 & 0.0540 & 0.1290 \\
\hline 9 & e & 9 & 3 & 0.0251 & 0.0300 & 0.0220 & 0.0520 \\
\hline 10 & & 10 & & 2707 & 0.0280 & 0.0190 & 0.0470 \\
\hline 11 & 10 & 11 & & 0619 & 0.1450 & 0.1040 & 0.2490 \\
\hline 12 & 11 & 12 & & & & & .2490 \\
\hline 13 & 12 & 13 & & 0 & 80 & 50 & .0130 \\
\hline 14 & 13 & 14 & 1.04 & 0.3450 & 0.0080 & 0.0055 & 0.0135 \\
\hline 15 & 14 & 15 & 1.0580 & 0.3496 & 0.0000 & 0.0000 & 0.0000 \\
\hline 16 & 15 & 16 & 0.1966 & 0.0650 & 0.0450 & 0.0300 & 0.0750 \\
\hline 17 & 16 & 17 & 274 & 1238 & 0.0600 & 0.0350 & 0.0950 \\
\hline 18 & 17 & 18 & 0041 & .0016 & 0.0600 & 0.0350 & 0.0950 \\
\hline 19 & 18 & 19 & & & 0.0000 & 0.0000 & 0.0000 \\
\hline 20 & 19 & 20 & & & & & \\
\hline 21 & 20 & 21 & & & & & \\
\hline 22 & 21 & 22 & & & & & \\
\hline 23 & 22 & 23 & 0.1591 & 0.0526 & 0.0000 & 0.0000 & 0.0000 \\
\hline 24 & 23 & 24 & 0.3463 & 0.1145 & 0.0280 & 0.0200 & 0.0480 \\
\hline 25 & 24 & 25 & 0.7488 & .2475 & 0.0000 & 0.0000 & 0.0000 \\
\hline 26 & 25 & 26 & 0.3089 & .1021 & 0.0140 & 0.0100 & 0.0240 \\
\hline 27 & 26 & 27 & 1732 & .0572 & 0.0000 & 0.0000 & 0.0000 \\
\hline 28 & 3 & 28 & 0.0044 & .0108 & 0.0260 & 0.0186 & 0.0446 \\
\hline 29 & 28 & 29 & & & & & 0446 \\
\hline 30 & & 30 & & & & & 0000 \\
\hline 31 & 30 & 31 & & & & & \\
\hline 32 & 31 & 32 & & & & & \\
\hline 33 & 32 & 33 & & & & & 00240 \\
\hline 34 & 33 & 34 & & & 0.0190 & 0.0140 & 0.0330 \\
\hline 35 & 34 & 35 & 1.4740 & 0.4873 & 0.0060 & 0.0040 & 0.0100 \\
\hline 36 & 3 & 36 & 1.4740 & 0.4873 & 0.0260 & 0.0186 & 0.0446 \\
\hline 37 & 36 & 37 & 0.0640 & 0.1565 & 0.0260 & 0.0186 & 0.0446 \\
\hline 38 & 37 & 38 & & 1230 & 0.0000 & 0.0000 & 0.0000 \\
\hline 39 & 38 & 39 & & & & & .0410 \\
\hline 40 & 39 & 40 & 0.001 & 0.0021 & 0.0240 & 0.0170 & 0.0410 \\
\hline 41 & 40 & 41 & 0.7283 & 0.8509 & 0.0010 & 0.0010 & 0.0020 \\
\hline 42 & 41 & 42 & 0.3100 & 0.3623 & 0.0000 & 0.0000 & 0.0000 \\
\hline 43 & 42 & 43 & & & 0.0060 & 0.0043 & 0.0103 \\
\hline 44 & 43 & 44 & & & 0.0000 & 0.0000 & 0.0000 \\
\hline 45 & 44 & 45 & & 0.1373 & & & \\
\hline 46 & 45 & 46 & 0.0009 & 0.0012 & 0.0390 & 0.0263 & 0.0653 \\
\hline 47 & 4 & 47 & & & & & 0.0000 \\
\hline 48 & 47 & 48 & & & 0.0790 & 0.0564 & 0.1354 \\
\hline 49 & 48 & 49 & & & 0.3840 & 0.2745 & 0.6585 \\
\hline 50 & 49 & 50 & 0.0822 & 0.2011 & 0.3840 & 0.2745 & 0.6585 \\
\hline
\end{tabular}

Tabel 2. Line Data dan Bus Data IEeE 69 Bus (Lanjutan)

\begin{tabular}{cccccccc}
\hline \hline & & & & & \multicolumn{3}{c}{ Daya Nominal } \\
\cline { 6 - 9 } Bus & $\begin{array}{c}\text { Dari } \\
\text { bus }\end{array}$ & $\begin{array}{c}\text { Ke } \\
\text { bus }\end{array}$ & $\mathbf{R}(\boldsymbol{\Omega})$ & $\mathbf{X}(\boldsymbol{\Omega})$ & $\begin{array}{c}\mathbf{P} \\
\text { (MW) }\end{array}$ & $\begin{array}{c}\mathbf{Q} \\
\text { (MVAR) }\end{array}$ & $\begin{array}{c}\mathbf{S} \\
\text { (MVA) }\end{array}$ \\
\hline 51 & 8 & 51 & 0.0928 & 0.0473 & 0.0400 & 0.0283 & 0.0683 \\
52 & 51 & 52 & 0.3319 & 0.1114 & 0.0030 & 0.0027 & 0.0057 \\
53 & 9 & 53 & 0.1740 & 0.0886 & 0.0040 & 0.0035 & 0.0075 \\
54 & 53 & 54 & 0.2030 & 0.1034 & 0.0260 & 0.0190 & 0.0450 \\
55 & 54 & 55 & 0.2842 & 0.1447 & 0.0240 & 0.0172 & 0.0412 \\
56 & 55 & 56 & 0.2813 & 0.1433 & 0.0000 & 0.0000 & 0.0000 \\
57 & 56 & 57 & 1.5900 & 0.5337 & 0.0000 & 0.0000 & 0.0000 \\
58 & 57 & 58 & 0.7837 & 0.2630 & 0.0000 & 0.0000 & 0.0000 \\
59 & 58 & 59 & 0.3042 & 0.1006 & 0.1000 & 0.0720 & 0.1720 \\
60 & 59 & 60 & 0.3861 & 0.1172 & 0.0000 & 0.0000 & 0.0000 \\
61 & 60 & 61 & 0.5075 & 0.2585 & 1.2440 & 0.8880 & 2.1320 \\
62 & 61 & 62 & 0.0974 & 0.0496 & 0.0320 & 0.0230 & 0.0550 \\
63 & 62 & 63 & 0.1450 & 0.0738 & 0.0000 & 0.0000 & 0.0000 \\
64 & 63 & 64 & 0.7105 & 0.3619 & 0.2270 & 0.1620 & 0.3890 \\
65 & 64 & 65 & 1.0410 & 0.5302 & 0.0590 & 0.0420 & 0.1010 \\
66 & 11 & 66 & 0.2012 & 0.0611 & 0.0180 & 0.0130 & 0.0310 \\
67 & 66 & 67 & 0.0047 & 0.0014 & 0.0180 & 0.0130 & 0.0310 \\
68 & 12 & 68 & 0.7394 & 0.2444 & 0.0280 & 0.0200 & 0.0480 \\
69 & 68 & 69 & 0.0047 & 0.0016 & 0.0280 & 0.0200 & 0.0480 \\
& & TOTAL & & $\mathbf{3 . 7 8 3 0}$ & $\mathbf{2 . 6 8 4 1}$ & $\mathbf{6 . 4 6 7 1}$ \\
\hline \hline & & & & & & & \\
\hline
\end{tabular}

\section{Algoritma Penempatan Distributed Generation}

Pada bab ini akan dijelaskan mengenai hasil dari analisis dan evaluasi kestabilan tegangan pada Test System IEEE 33 Bus dan Test System IEEE 69 Bus dengan menggunakan metode Continuation Power Flow (CPF), analisis ini dilakukan saat sebelum dan sesudah penambahan Distributed Generation (DG). Tujuan utama dari metode Continuation Power Flow (CPF) adalah untuk mencari bus yang paling sensitif mengalami Voltage Collapse ketika dilakukan penambahan beban secara kontinyu tanpa mempertimbangkan rating peralatan, sehingga dengan mengetahui adanya bus paling sensitif maka bus tersebut dapat dijadikan sebagai referensi penempatan unit DG untuk dilakukan evaluasi kestabilan tegangan dengan adanya penambahan unit DG, evaluasi kestabilan tegangan yang dilakukan dengan menambahkan unit DG akan berdampak pada kestabilan tegangan sistem salah satunya adalah meningkatkan profil tegangan dan menjadikan sistem tidak mudah mengalami Voltage Collapse ketika dilakukan penambahan beban secara kontinyu.

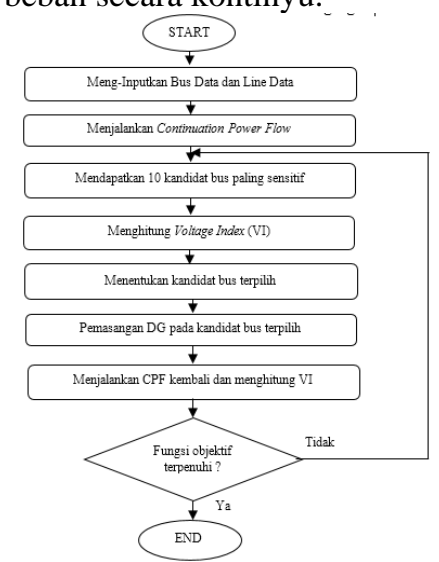

Gambar 3. Diagram Alir Penempatan Distributed Generation (DG) 
Simulasi ini berawal dari menginputkan line data dan bus data, setelah itu simulasi Continuation Power Flow (CPF) dijalankan dan akan mendapatkan 10 bus kandidat bus paling sensitif, dimana 10 kandidat bus paling sensitive didapatkan berdasarkan 10 bus dengan nilai gradient terbesar, setelah itu 10 kandidat bus tersebut akan dipasangkan DG secara bergantian untuk dihitung nilai voltage index (VI) nya, kandidat bus dengan nilai voltage index (VI) terendah akan dijadikan sebagai kandidat terpilih pemasangan DG, proses ini akan terus berulang hingga voltage index iterasi saat ini lebih besar dari voltage index sebelumnya $\left(\mathrm{VI}_{\mathrm{k}}>\mathrm{VI}_{\mathrm{k}-1}\right)$.

Voltage Index (VI) merupakan sebuah indikator untuk menentukan deviasi tegangan antara tegangan bus yang diinginkan $\left(V_{i, 0}\right)$ biasanya adalah 1 p.u. dengan tegangan bus setelah penempatan DG $\left(V_{i, 1}\right)$. Semakin rendah nilai VI menunjukan kinerja DG pada sistem semakin baik.

$$
V I=\sum_{i=1}^{n}\left(V_{i, 0}-V_{i, 1}\right)^{2}
$$

Kapasitas DG yang digunakan berdasarkan penetration level yang diberikan dan dapat dicari menggunakan persamaan (18).

$$
P L=\frac{S_{D G}}{S_{\text {load }}} \times 100 \%
$$

Penetrasi level pada unit DG dibutuhkan untuk menentukan kapasitas DG yang digunakan berdasarkan nilai presentasi dari penetrasi level DG yang dikalikan dengan total daya semu jaringan $\left(S_{\text {load }}\right)^{[5]}$.

\section{HASIL SIMULASI DAN ANALISIS}

\section{A. Hasil Pengujian IEEE 33 Bus}

Test System IEEE 33 Bus memiliki total daya aktif dan daya reaktif sebesar 3.7150 MW dan 2.3000 MVar, sehingga penambahan unit DG sebesar $40 \%$ akan bernilai 1.4860 MW dan 0.9200 MVar.

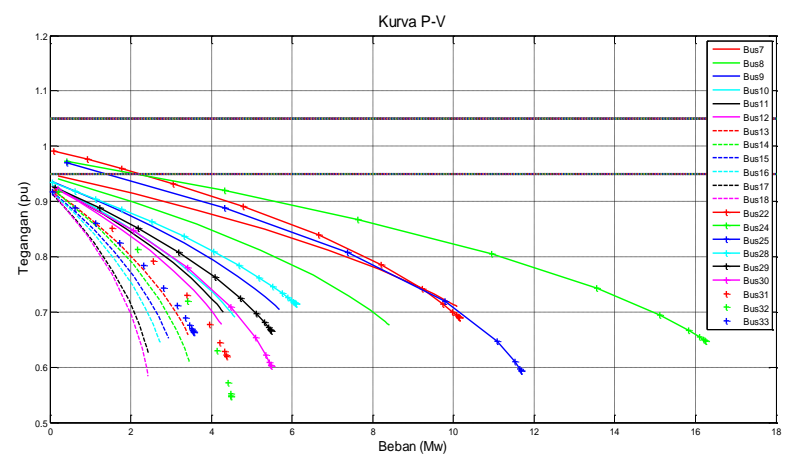

Gambar 4. Kurva P-V Sebelum Penambahan Distributed Generation (DG)

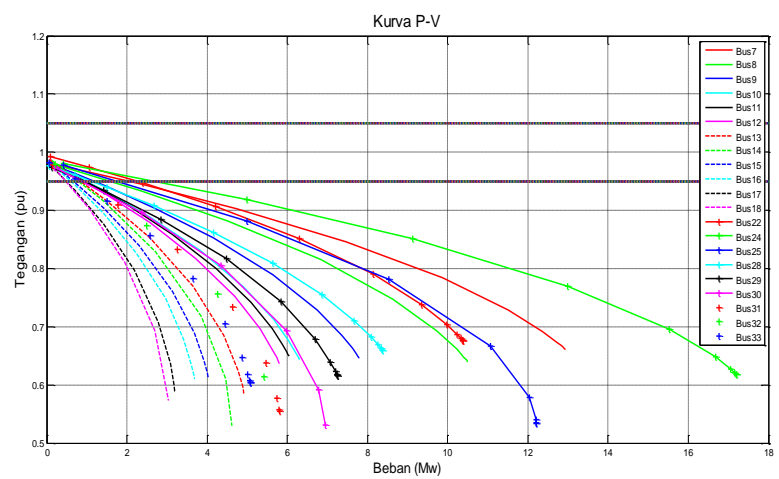

Gambar 5. Kurva P-V Setelah Penambahan Distributed Generation (DG) di bus 13 dan 33
Penentuan lokasi DG pada bus 13 dan bus 33 ditetapkan berdasarkan nilai voltage index terendah, tidak dilakukan penambahan hingga 3 unit DG karena nilai VI dengan 3 unit DG lebih besar daripada 2 unit DG seperti yang terlihat pada Tabel 1 .

TABEL 3. VOLTAGE INDEX TEST SYSTEM IEEE 33 BUS VOLTAGE INDEX

\begin{tabular}{|c|c|}
\hline Base Case & 0.1170943 \\
\hline DG 40\% di Bus 13 & 0.0190695 \\
\hline DG 20\% di Bus 13, 33 & 0.0098370 \\
\hline DG 13.33\% di Bus 13, 33, 15 & 0.0098900 \\
\hline
\end{tabular}

Apabila profil tegangan seluruh case dibandingkan maka perbedaan akan terlihat pada Gambar 6.

\section{Perbandingan Profil Tegangan}

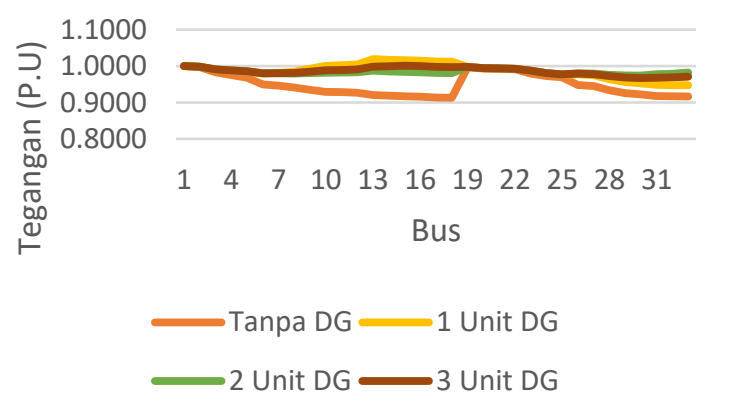

Gambar 6. Perbandingan Profil Tegangan Test System 33 Bus

\section{B. Hasil Pengujian IEEE 69 Bus}

Test System IEEE 69 Bus memiliki total daya aktif dan daya reaktif sebesar 3.7830 MW dan 2.6841 MVar, sehingga penambahan unit DG sebesar $40 \%$ akan bernilai 1.5132 MW dan 1.07364 MVar.

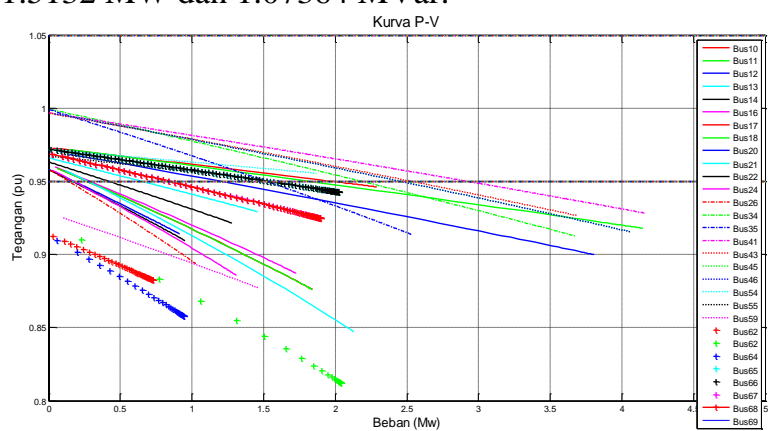

Gambar 7. Kurva P-V Sebelum Penambahan Distributed Generation (DG)

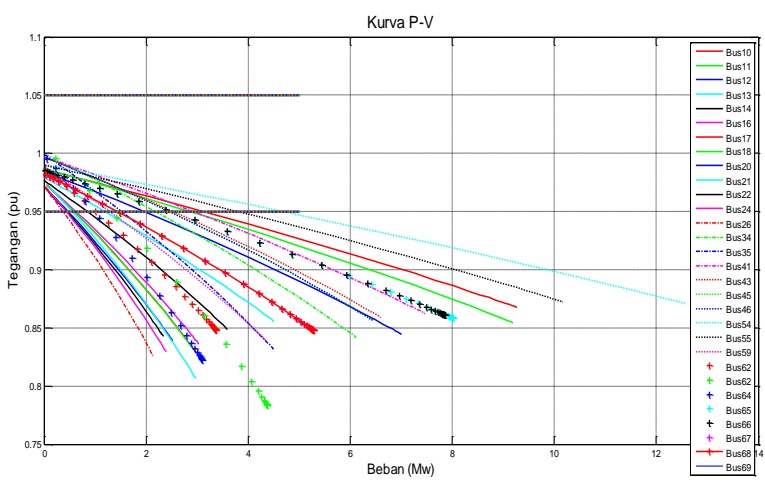

Gambar 8. Kurva P-V Setelah Penambahan Distributed Generation (DG) di bus 64 
TABel 4. Voltage IndeX Test System IEEE 69 bus VOLTAGE INDEX

\begin{tabular}{|c|c|}
\hline Base Case & 0.0979570 \\
\hline DG 40\% di Bus 64 & 0.015661 \\
\hline DG 20\% di Bus 64, 65 & 0.023085 \\
\hline
\end{tabular}

Apabila profil tegangan seluruh case dibandingkan maka perbedaan akan terlihat pada Gambar 9.

\section{Perbandingan Profil Tegangan}

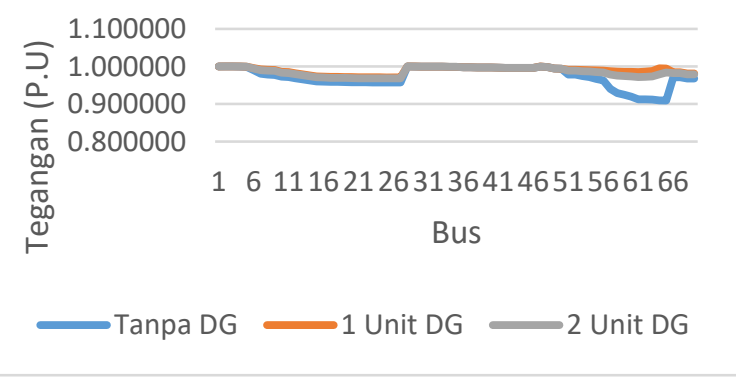

Gambar 9. Perbandingan Profi Tegangan Test System 69 Bus

\section{KESIMPULAN DAN SARAN}

Berdasarkan hasil simulasi dan analisis dapat disimpulkan bahwa Metode Continuation Power Flow dapat diaplikasikan sebagai salah satu metode untuk menentukan lokasi penempatan DG berdasarkan bus sensitif terjadinya drop jatuh tegangan karena dari hasil simulasi tersebut menunjukan bahwa dengan adanya penambahan DG yang dilakukan pada sistem distribusi akan memiliki kemampuan sistem yang lebih stabil dan memiliki profil tegangan yang lebih baik.

\section{A. Saran}

Saran yang dapat diberikan untuk perbaikan dan pengembangan dalam tugas akhir ini adalah :

1. Metode Continuation Power Flow (CPF) dapat diaplikasikan sebagai metode untuk menganalisis kestabilan sistem dengan adanya penambahan beban.

2. Perlu dilakukan pengembangan dalam hal memberikan kapasitas Distributed Generation (DG) yang akan diimplementasikan

3. Perlu dilakukan pengembangan dalam hal pemodelam Distributed Generation (DG) untuk menjaga tegangan sistem

\section{DAFTAR PUSTAKA}

[1] N.Sahu, "Voltage Regulators Placement in Unbalance Radial Distrbution Systems for Loss Minimization Using Particle Swarm Optimization", IJRREE, Vol.1, Issue 3, pp : (11-22), Dec.2014

[2] P. Kundur, "Voltage Stability, Power System Stability and Control”. 959-1019. New York : McGraw-Hill 1994

[3] W.El-Khattam, M.M.A. Salama, "Distributed Generation Technologies, Definitions and Benefits", ELSEVIER Electric Power System Ressearch 71 (2004) 119-129, Jan.2004

[4] Ackerman, T. Andersson, G. Soder, L.,’Distributed Generation : a definition, Electric Power Systems Research 57, Elsevier, 2001, pp.195-2004

[5] H.Hedayanti, S.A. Nabaviniaki, and A. Akbarimajd, "A Method for Placement of DG units in distribution network", IEEE Trans. Power Del., vol.23 no.3, pp. 1620-1628, Jul.2008

[6] M. Ettehadi, H.Ghasemi, S. Vaez-Zadeh, "Voltage Stability Based DG Placement in Distribution Networks", IEEE Trans. Power Del., vol. 28, no.1, Jan.2013

[7] Fathurohman, A, "Analisis Stabilitas Transien Dan Tegangan Pada Sistem Tenaga Listrik Akibat Instalasi Pembangkitan Terdistribusi”, Digilib.ITS, Surabaya 2016

[8] Ramadhan, A, "Analisis Stabilitas Tegangan Pada Jaringan Distribusi Radial Tiga Fasa Tak Seimbang”, Digilib.ITS, Surabaya 2014

[9] Standar IEEE

[10] Abdel-Akher, Mamdouh, "Voltage Stability Analysis Of Unbalanced Distributiom System Using Backward/Forward Sweep Load-Flow Analysis Method With Secant Predictor", IET Gener. Transm. Distrib. 2013, Vol.7 Iss. 3, pp. 309-317 309

[11] K. Purchala, R. Belmans. "Distributed Generation and Grid Integration Issues", Imperial College, London (2003)

[12] W.N. Rizka, "Alogritma Aliran Daya untuk SIstem Distribusi Radila dengan Beban Sensitif Tegangan”, Digilib.ITS, Surabaya 2014

[13] D.K. Septy, "Pengembangan Software Alanisis Aliran Daya Seimbang Pada Sistem Distribusi Aktif Menggunakan Metode Modified Backward Forward”, Digilib.ITS, Surabaya 2015

[14] F. Jiang, Z, Zhang, "Impact of Distributed Generation on Voltage profile and Losses of Distribuion Systems", Porceedings of the $32^{\text {nd }}$ Chinese Control Conference, 2013 